\title{
Archaeological Investigations at the Pine Snake Site, an Allen Phase Settlement on Flat Creek in Northwestern Cherokee County, Texas
}

Timothy K. Perttula

Heritage Research Center, Stephen F. Austin State University

Bo Nelson

Heritage Research Center, Stephen F. Austin State University

Mark Walters

Heritage Research Center, Stephen F. Austin State University

James Feathers

Follow this and additional works at: https://scholarworks.sfasu.edu/ita

Part of the American Material Culture Commons, Archaeological Anthropology Commons, Environmental Studies Commons, Other American Studies Commons, Other Arts and Humanities Commons, Other History of Art, Architecture, and Archaeology Commons, and the United States History Commons

Tell us how this article helped you.

This Article is brought to you for free and open access by the Center for Regional Heritage Research at SFA ScholarWorks. It has been accepted for inclusion in Index of Texas Archaeology: Open Access Gray Literature from the Lone Star State by an authorized editor of SFA ScholarWorks. For more information, please contact cdsscholarworks@sfasu.edu. 


\section{Archaeological Investigations at the Pine Snake Site, an Allen Phase Settlement on Flat Creek in Northwestern Cherokee County, Texas}

\section{Creative Commons License}

\section{(c) (1) \&}

This work is licensed under a Creative Commons Attribution-NonCommercial 4.0 International License 


\title{
Archaeological Investigations at the Pine Snake Site, an Allen Phase Settlement on Flat Creek in Northwestern Cherokee County, Texas
}

\author{
Timothy K. Perttula, Bo Nelson, and Mark Walters, \\ with a contribution by James Feathers
}

\section{INTRODUCTION}

The Pine Snake site is a recently discovered late $17^{\text {th }}$ to early $18^{\text {th }}$ century Caddo Indian archaeological site located on private land in the northwestern part of Cherokee County, Texas, in the valley of a westwardflowing tributary to the Neches River. This is an area of the Pineywoods of East Texas that contains extensive numbers of Caddo archaeological sites along all major and minor streams (see Anderson et al. 1974; Kleinschmidt 1982; Perttula and Nelson 2007, 2009a, 2009b; Walters and Perttula 2012). Post-A.D. 1400 Frankston phase and post-A.D. 1650 Historic Caddo Allen phase sites, especially cemeteries dating to either phase, are particularly abundant in this part of East Texas (Cole 1975; Kleinschmidt 1982; Marceaux 2007, 2011; Perttula 2007a, 2007b, 2008, 2010, 2011). This article summarizes the findings from archaeological investigations we completed at the Pine Snake site in late 2008. They have produced important information on the domestic archaeological record at a well preserved Allen phase habitation site.

\section{SETTING}

This historic Caddo site has an spatially extensive archaeological deposit. It extends for more than 600 $\mathrm{m}$ along a narrow ridge top and ridge slope (370-400 feet amsl), as well as a swale or saddle, reminiscent of the setting of the nearby Kah-hah-ko-wha site (41CE354) on Flat Creek (Perttula and Nelson 2007), and a probable spring-fed intermittent drainage area, now dry (Figure 1). The current channel of Flat Creek is more than $800 \mathrm{~m}$ to the north; a seasonal tributary to Flat Creek also lies ca. $150 \mathrm{~m}$ to the east and southeast.

The vegetation on the ridge top and ridge slope landforms is a pine plantation that is approximately 10 years old. Consequently, surface visibility is less than $10 \%$ due to a thick understory of brush and vines. There is evidence of ridge rows of soil on the site, evidence of the clearing preparations in advance of planting the pine trees in rows.

\section{WORK COMPLETED AT THE SITE}

Thirty-nine shovel tests were first excavated on the ridge top and ridge slope to define the spatial limits of the site (see Figure 1). A total of 29 of the shovel tests excavated at the Pine Snake site were found to contain archaeological materials that occurred between $0-60 \mathrm{~cm}$ bs in Nacogdoches fine sandy loam sediments (see Mowery and Oakes 1959). These were principally ceramic vessel sherds (64\%) that were concentrated in two areas at the northern (ST 576 and ST 581) and southern (ST 548-550, 552-555, and 557-561) ends of the site (see Figure 1). These concentrations surely relate to archaeological evidence of two or more Historic Caddo farmstead compounds preserved at the Pine Snake site. Other shovel tests were noted to contain lithic artifacts and animal bone, with most of the latter found to be in the southern ceramic concentration. The estimated spatial extent of the site is $20,100 \mathrm{~m}^{2}$, or approximately 5.0 acres.

During the course of shovel testing, one shovel test (ST 558) in the southern ceramic concentration (see Figure 1) encountered a lens of darker soil, a mussel shell fragment, and a high number of ceramic sherds between $0-40 \mathrm{~cm}$ bs. Another shovel test (Unit 778), rectangular-shaped and about $70 \times 100 \mathrm{~cm}$ in size to permit a better examination of the profile, was excavated adjacent to it (Figure 2). Encountered in Unit 778 was a zone of ash between $32-40 \mathrm{~cm}$ bs, followed by a hard, compact oxidized soil between $40-46 \mathrm{~cm}$ bs 


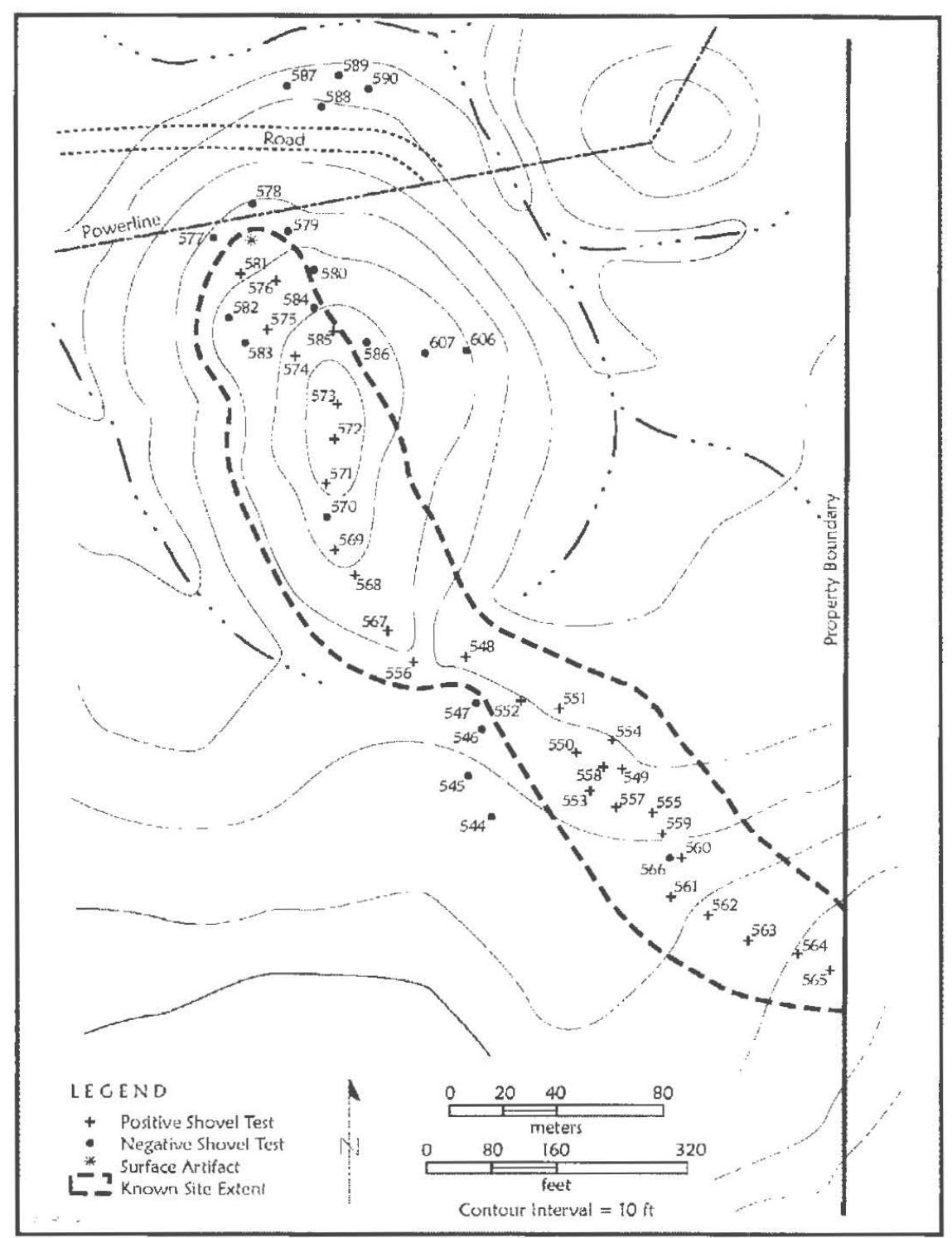

Figure 1. Map of the Pine Snake site.

(Figure 3), resting directly on, or excavated slightly into, the clay subsoil. This deposit appeared to represent a basin-shaped hearth (estimated at that time as at least $115 \mathrm{~cm}$ in diameter) filled with ash and darker sediments. Ceramic sherds, wood charcoal, charred nutshells, animal bone, and mussel shell fragments were noted amidst this hearth feature, particularly between $20-40 \mathrm{~cm}$ bs.

The overall density of artifacts noted in the positive shovel tests (excluding the irregular-sized Unit 778) is considerable, at 2.69 per positive shovel test, or ca. 21.5 artifacts per $\mathrm{m}^{2}$. In terms of the ceramic sherds, the highest densities noted in the shovel tests included 14 sherds in ST 558, nine sherds in ST 555, and eight sherds in ST 550, all in the southern concentration at the site (see Figure 1). Also noted in this same area were several Perdiz arrow point fragments (see below).

Subsequent to the completion of the shovel testing, additional controlled excavations were done in the southern part of the Pine Snake to better define the archaeological character of the hearth feature, as well as to examine the archaeological deposits in more detail around the hearth. The additional work included the excavation of five $1 \times 1 \mathrm{~m}$ units (Units 782-786) around ST 558 and Unit 778 (see Figurc 2) as well as a ca. 


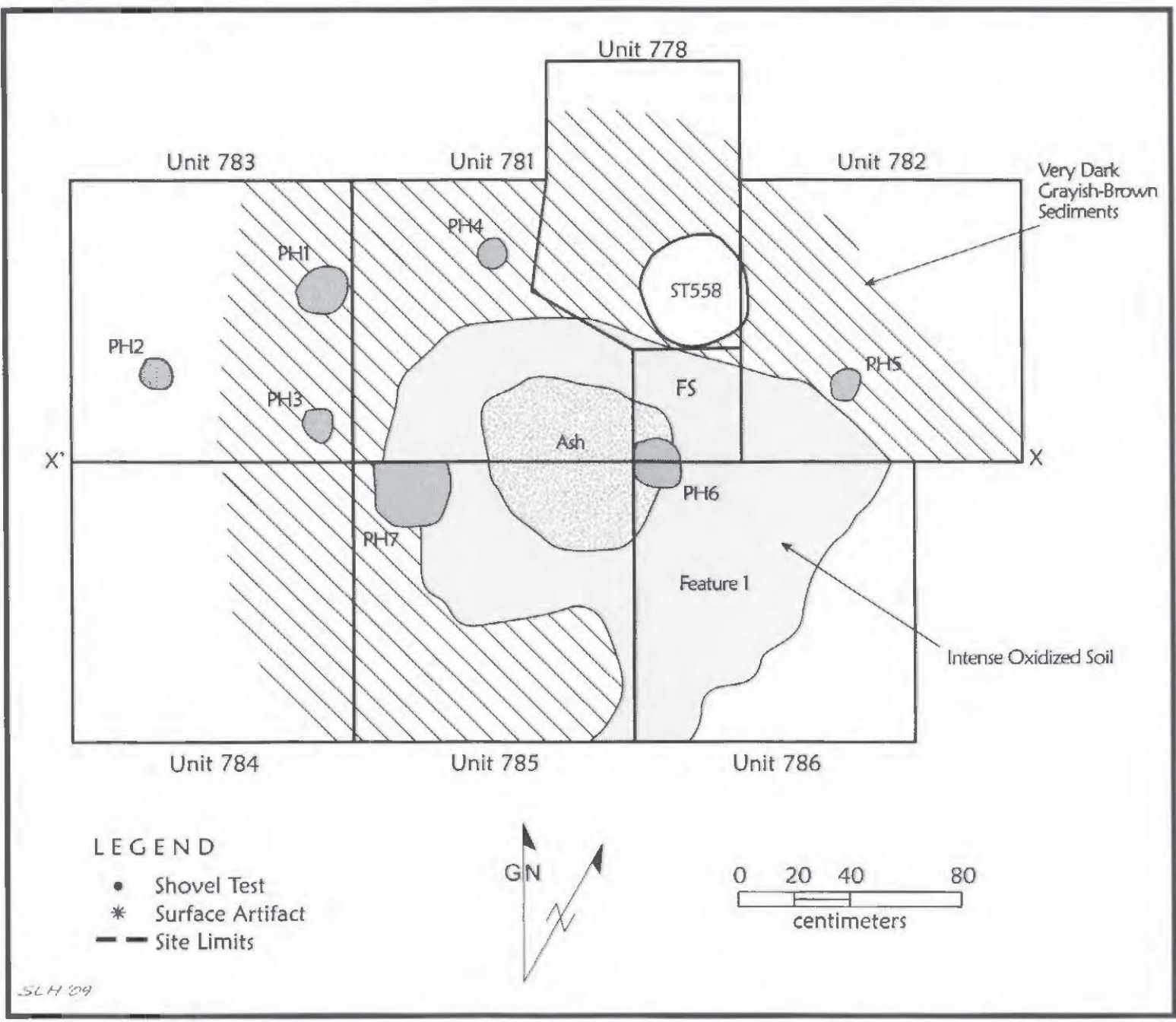

Figure 2. Plan of excavations in the southern part of the Pine Snake site.

$70 \mathrm{~cm} \times 1 \mathrm{~m}$ unit (Unit 781). Various fine-screen samples were taken from Units 781-783 and the post hole features exposed in the work (see below and Appendix 1). Additionally, a $40 \times 40 \mathrm{~cm}$ fine-screen unit was excavated just south of ST 558 (see Figure 2). This work exposed a large hearth feature (Feature 1) that most likely represents a central hearth inside a Caddo domicile, along with seven post holes, as well as an abundance of Historic Caddo Allen phase artifacts discarded in and around the hearth.

The archaeological deposits in this part of the Pine Snake site range between $30-50 \mathrm{~cm}$ in thickness overlying a red clay subsoil (Figure 4). The uppermost deposit (Zone 1) is a dark yellowish-brown (10YR 3/4) sandy loam A-horizon that ranges from $12-40 \mathrm{~cm}$ in thickness. Outside the area of the Feature 1 hearth, the second soil zone (Zone 2) is a strong brown (7.5YR 4/6) sandy loam E-horizon about $15 \mathrm{~cm}$ in thickness. Below this is a red (2.5YR 4/6) clay B-horizon (Zone 3) (Figure 4). In the area of the Feature 1 hearth, lying below Zone 1 is a ca. $10-20 \mathrm{~cm}$ thick very dark grayish-brown (10YR 3/2) sandy loam (Zone 4) occupational deposit that rests directly above a lens of ash and an oxidized deposit, but this charcoal-stained sediment also extends in a $50-80 \mathrm{~cm}$ wide band outside of, but adjacent to, the oxidized basin (see Figure 2). Below Zone 4 is a thin gray ash lens (Zone $5 \mathrm{a}$ ), between $3-5 \mathrm{~cm}$ in thickness, that accumulated through hearth use atop the oxidized basin. The oxidized basin sediments (Zone 5b) are a hard baked red (2.5YR 4/8) sandy loam that are a maximum of $16 \mathrm{~cm}$ in thickness (see Figure 4). The oxidized basin appears to have been excavated into the Zone 3 B-horizon approximately $12 \mathrm{~cm}$ in the deepest part of the hearth basin. 


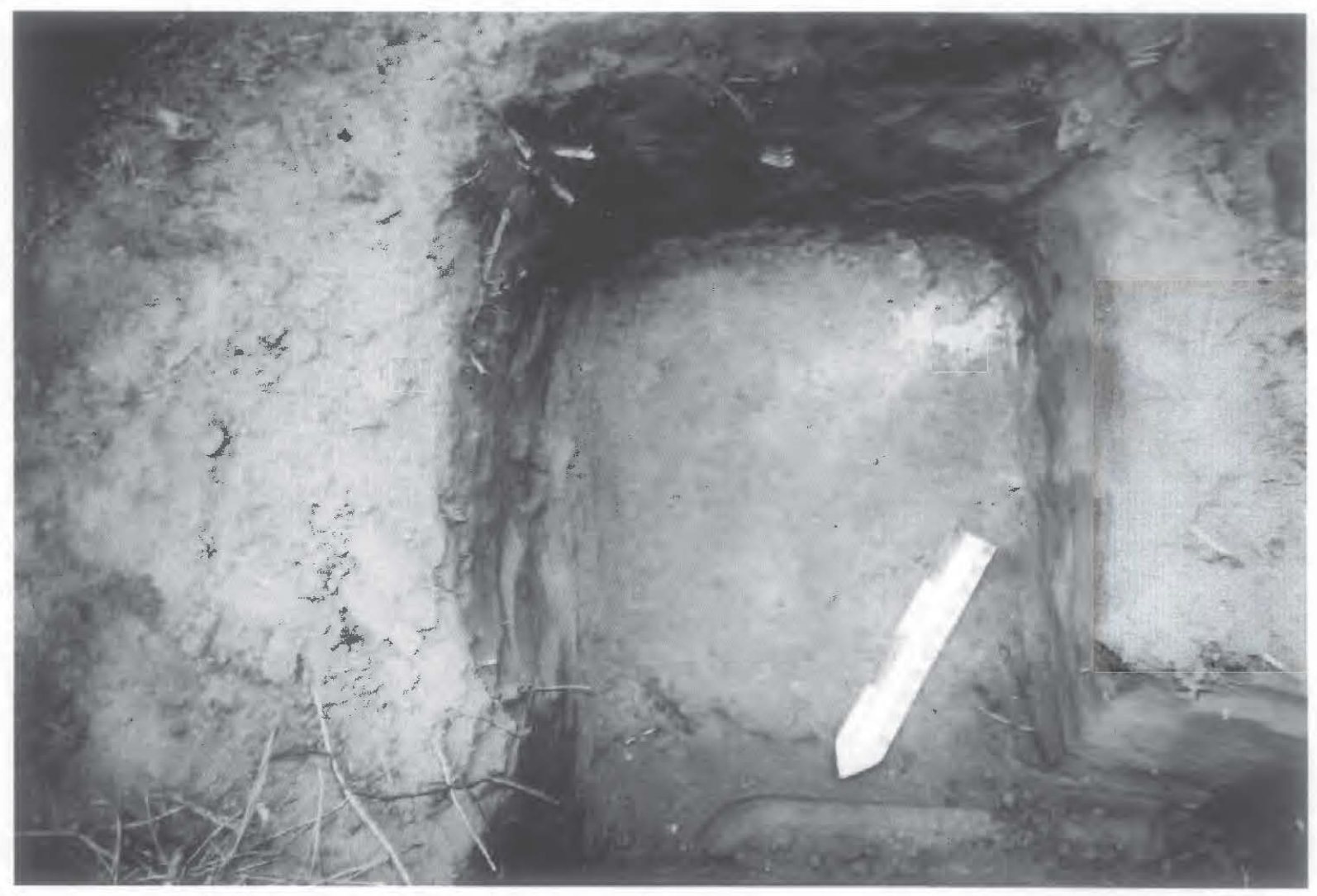

Figure 3. Looking down at the top of the oxidized zone in a hearth feature exposed in ST 778 at the Pine Snake site.

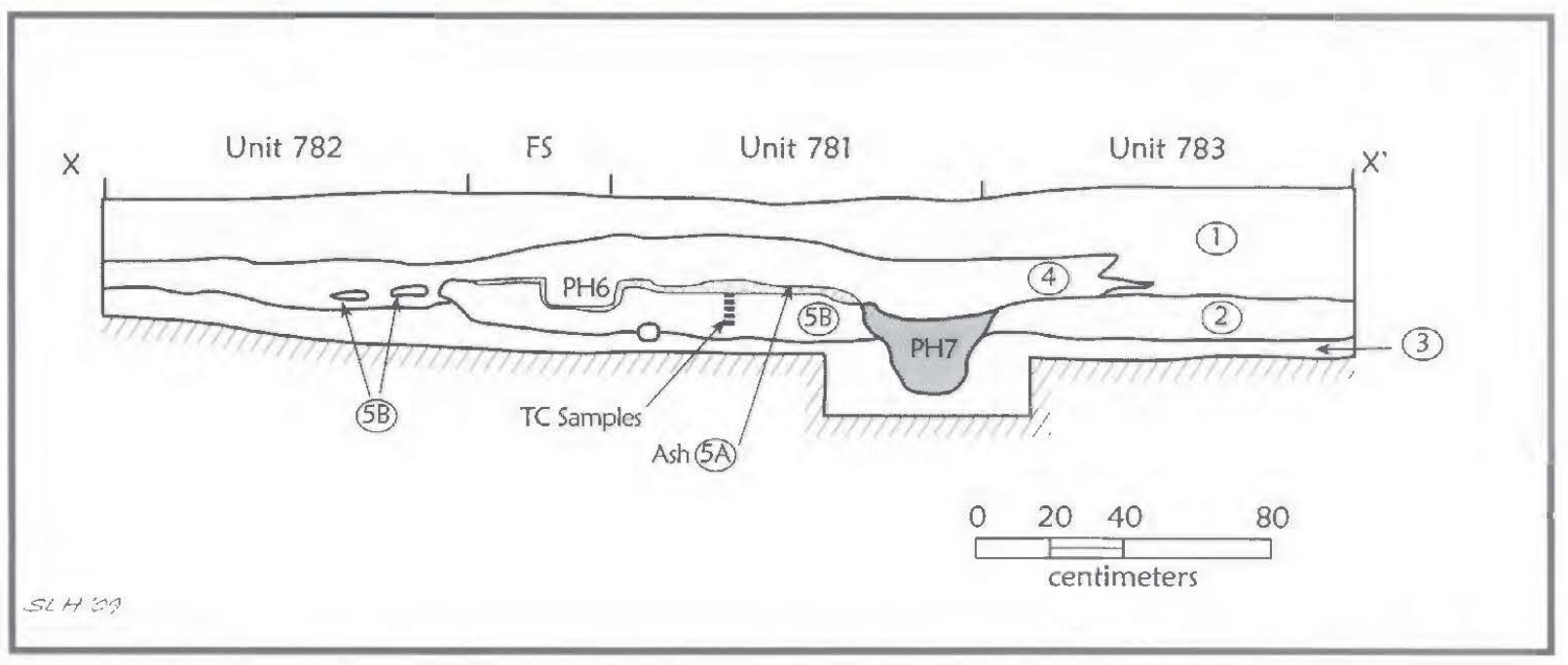

Figure 4. Profile of Units 781-783 and the Feature 1 hearth.

\section{FEATURES}

The features documented in the limited archaeological investigations at the Pine Snake site include the Feature 1 hearth and seven post holes (PH 1-7) (see Figure 2). One of the post holes (PH 6) intrudes into the Zone 5a ash deposits in the hearth (see Figure 4), and clearly postdates its accumulation. The top of PH 7 was exposed underneath Zone 4 deposits, but is coeval with the Feature 1 ash and oxidized basin deposits (see Figure 4), and thus it is not a central structure post; our excavations did not identify a central post associated with Feature 1. 
Feature 1 consists of several associated sediments. First is an intensely oxidized red sandy loam (Zone $5 b$ ) hearth basin that is approximately $110 \mathrm{~cm}$ (north-south) x $180 \mathrm{~cm}$ (east-west) (see Figure 2). In the center of the hearth, the basin extends from $31-48 \mathrm{~cm}$ bs (see Figure 4). The thickness and hard-baked character of the basin indicates that the hearth was repeatedly used and re-used for a number of years by the Caddo peoples living at the Pine Snake site.

In the approximate center of the Zone $5 \mathrm{~b}$ basin is a concentrated $60 \times 65 \mathrm{~cm}$ area of gray ash (Zone $5 a)$. The top of the ash is exposed at $28 \mathrm{~cm}$ bs (see Figure 4). Above this is the Zone 4 deposits $(13-28 \mathrm{~cm}$ bs) of very dark grayish-brown sediments (with charcoal flecks and staining) that are likely to have been raked out of the hearth to clean and empty the basin. This band of charcoal-stained sediments is present to the immediate north, west, and south of the oxidized basin (see Figure 2).

The Feature 1 hearth was probably located inside a structure, although the excavations were not sufficiently intensive or of a large-enough scale to identify a structure wall post pattern. Such a hearth, with a concentrated and well-preserved ash deposit in the central part of the basin, would have been "used almost exclusively for warming, as suggested by white ash smoldering fires, which are less suitable for cooking than the higher-intensity outdoor fires with their constant flow of oxygen to fuel the flames" (Shafer 2003:37).

\section{Post holes}

PH 1-5 are arranged in a semi-circle along the northern and western parts of the Feature 1 hearth. Given their placement, and their generally small size (Figure 5), they may mark the construction of a screen along one side of the hearth while it was in use. The exposed tops of the post holes are at $33-35 \mathrm{~cm}$ bs, and they extend to $38 \mathrm{~cm}$ bs (PH 5), $41 \mathrm{~cm}$ bs (PH 4), $44 \mathrm{~cm}$ bs (PH 2 and PH 3), or $47 \mathrm{~cm}$ bs (PH 1). Only PH 1, PH 4 , and PH 5 were set in the Zone 3 clay B-horizon. The post hole fill is either a dark grayish-brown sandy loam with charcoal flecks (PH 1,PH 3), a dark yellowish-brown (10YR 4/4) sandy loam with charcoal flecks (PH 2), or a dark brown (IOYR 3/2) sandy loam with no charcoal flecking. With the exception of PH 1, which is $19 \mathrm{~cm}$ in diameter and a typical size for a wall or smaller interior post support of a Caddo house, post hole diameters range from $10-13 \mathrm{~cm}$, much too small for them to have likely served as wall posts.

PH 6 intersects the Zone 5a ash in Feature 1, and postdates the accumulation of the ash (see Figures 2 and 4). This post, with straight sides and a flat bottom, is approximately $19 \mathrm{~cm}$ in diameter, and extends from $28-37 \mathrm{~cm}$ bs. Its fill is a very dark grayish-brown sandy loam (Zone 4).

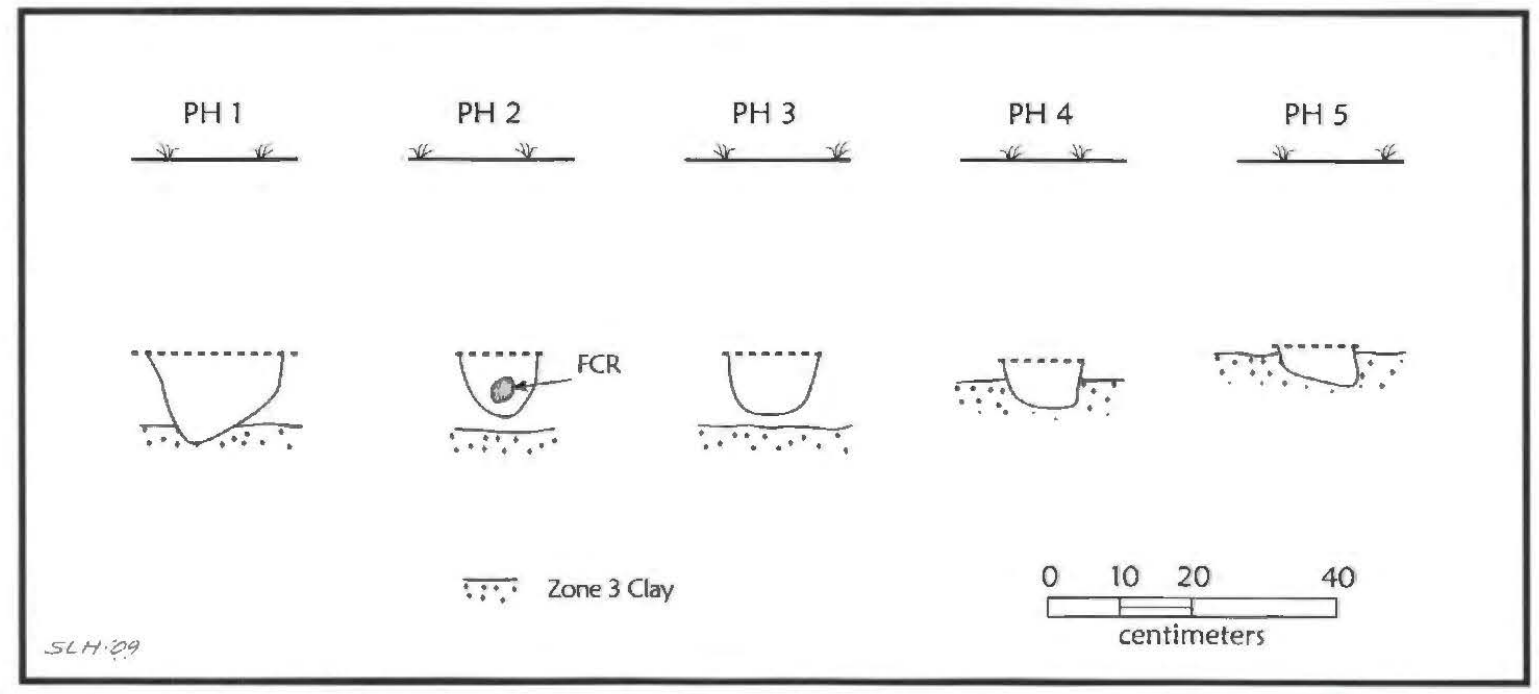

Figure 5. Profiles of post holes 1-5 at the Pine Snake site. 
$\mathrm{PH} 7$ is a larger post feature (26 $\mathrm{cm}$ in diameter), probably a support post, that had been placed along the western side of the oxidized basin, probably cutting through it, or less likely set next to it when it was in use (see Figures 2 and 4 ). The fact that the post was first recognized only below the Zone 4 hearth debris suggests it had been placed at approximately the same time as the hearth was in use; hearth sediments were incorporated into the fill. This post has sloping sides and a rounded bottom, and extends from $35-66 \mathrm{~cm}$ bs. The fill of this post is primarily a strong brown sandy loam (Zone 2 ) that is mottled with very dark grayishbrown sandy loam (Zone 4 ) and chunks of oxidized soil.

\section{THERMOLUMINESCENCE DATING, by James Feathers}

Two ceramic sherds and a chunk of the intensely oxidized Feature 1 hearth basin were submitted to the University of Washington Luminescence Dating Laboratory for thermoluminescence dating (Feathers 2010). The two sherds - both parallel brushed cooking jar body sherds - are from Unit $785(24 \mathrm{~cm}$ bs $)$ and Unit 786 (28 cm bs). The sample of oxidized soil from Feature 1 is from $39-41 \mathrm{~cm}$ bs in Unit 785 .

Dose rate measurements were made on each sample as well as an associated sediment sample. Due to time limitations, measurements on three of the sediment samples did not get completed, but variation in radioactivity among them was not great, so an average from the same site was used for age calculation for those particular samples. The difference in radioactivity between sherds and associated sediments was also not great in most cases, suggesting the ceramics were made from similar material as the sediments. Dose rates were determined using alpha counting and flame photometry. The beta dose rate calculated from these measurements was compared with the beta dose rate measured directly by beta counting. These were in agreement for nine of the samples, but differed for the other seven. In the latter case, the beta dose rate from beta counting was used for age calculation. The cause of the discrepancy in beta dose rates is not certain, but it could relate to disequilibrium in the uranium decay chain. Moisture content was estimated as $80 \pm 20$ $\%$ of saturated value for the sherds, and $10 \pm 5$ percent for the sediments. Table 1 gives all relevant data, including the total dose rate for each sample.

Table 1. TL and OSL data for samples from the Pine Snake site.

\begin{tabular}{|c|c|c|c|c|c|c|}
\hline \multirow[t]{2}{*}{ Sample } & \multirow[t]{2}{*}{$\begin{array}{l}{ }^{238} \mathrm{U} \\
(\mathrm{ppm})\end{array}$} & \multirow[t]{2}{*}{$\begin{array}{l}{ }^{233} \mathrm{Th} \\
(\mathrm{ppm})\end{array}$} & \multirow[t]{2}{*}{$\begin{array}{c}K \\
(\%)\end{array}$} & \multicolumn{2}{|c|}{$\begin{array}{c}\text { Beta dose rate } \\
(G y / k a)\end{array}$} & \multirow{2}{*}{$\begin{array}{c}\text { Total dose } \\
\text { rate }^{*} \\
(G y / k a)\end{array}$} \\
\hline & & & & $\begin{array}{c}\text { B- } \\
\text { counting }\end{array}$ & $\begin{array}{c}\alpha- \\
\text { counting/ } \\
\text { flame } \\
\text { photometry }\end{array}$ & \\
\hline$U W 1964$ & $2.19 \pm 0.15$ & $3.56 \pm 0.76$ & $0.89 \pm 0.06$ & $1.02 \pm 0.08$ & $1.13 \pm 0.06$ & $2.57 \pm 0.16$ \\
\hline UW1965 & $5.41 \pm 0.35$ & $14.12 \pm 1.43$ & $0.80 \pm 0.03$ & $1.53+0.14$ & $1.82 \pm 0.07$ & $5.93 \pm 0.73$ \\
\hline Sedimcnt & $1.97 \pm 0.14$ & $3.21 \pm 0.72$ & $0.73 \pm 0.05$ & & & \\
\hline UW1966 & $2.95 \pm 0.20$ & $6.56 \pm 0.99$ & $1.07 \pm 0.06$ & $1.85 \pm 0.16$ & $1.47 \pm 0.06$ & $3.81 \pm .23$ \\
\hline
\end{tabular}

*Dose rate calculated for TL. It will he slightly lower for OSI . hecause of lower alpha efficiency.

Equivalent dose was determined by TL, IRSL and OSL. The TL measurements, in general, were characterized by poor plateaus (Table 2). In only two samples did the plateau (region of constant equivalent dose) extend beyond $320^{\circ} \mathrm{C}$, symptomatic of relatively low firing conditions. In half the samples there was some sensitivity change with second glows. All but three growth curves were fit with linear functions. Anomalous fading was ubiquitous, and apparent in all but three samples (Table 2).

OSL was measured on 5 or 6 aliquots per sample. The OSL signal was generally strong, at least 10 times the intensity of the IRSL signal (in the SAR protocol). This is typical for ceramics and because 
Table 2. TL measurements.

\begin{tabular}{c|cccc}
\hline Sample & Plateau $\left({ }^{\circ} \mathrm{C}\right)$ & $I^{\text {st }} / 2^{\text {nd }}$ ratio $^{*}$ & fit & g-value** \\
\hline UW1964 & $250-290$ & 1 & Linear & $13.3 \pm 2.31$ \\
UW1965 & $260-340$ & $0.72 \pm 0.16$ & Linear & $7.03 \pm 2.95$ \\
UW1966 & $270-340$ & $1.50 \pm 0.12$ & linear & $8.48 \pm 1.85$ \\
\hline
\end{tabular}

*Refers to slope ratio between the first and second glow growth curves.

A glow refers to luminescence as a function of temperature; a second glow comes after heating to $450^{\circ} \mathrm{C}$.

** g-value is the fading rate expressed as \% per decade, where a decade is a power of 10 .

IRSL mainly stems from feldspars, which are involved in anomalous fading, this probably means the OSL signal does not fade appreciably. Weak signal allowed equivalent dose for IRSL to be measured on more than two aliquots for only one of the samples. Equivalent dose values are given in Table 3 . The equivalent dose values differ among TL, IRSL and OSL, which is not surprising given that the b-values (which reflect the lower efficiency of alpha irradiation in producing luminescence) also differ. However, the OSL equivalent dose is unusually low, when compared with the TL and IRSL values, for most samples, the significance of which will be taken up next. The b-values are also given in Table 3 . These are fairly typical values, although the IRSL values are based on limited data due to a weak signal. The IRSL/OSL b-values were not measured for UW1964, due to an oversight; an average value was used for OSL age calculation.

Table 3. Equivalent dose values for TL, IRSL, and OSL.

\begin{tabular}{c|ccc|ccc}
\hline Sample & \multicolumn{3}{|c}{ Equivalent dose $(G y)$} & \multicolumn{3}{c}{ b-value $\left(G y \mu^{2}\right)$} \\
\cline { 2 - 7 } & $T L$ & IRSL & OSL & $T L$ & IRSL & OSL \\
UW1964 & $2.24 \pm 0.16$ & $0.95 \pm 0.54$ & $1.11 \pm 0.03$ & $2.12 \pm 0.26$ & & \\
UW1965 & $3.45 \pm 0.71$ & $1.58 \pm 0.76$ & $1.53 \pm 0.07$ & $2.72 \pm 0.47$ & $1.25 \pm 0.22$ & $0.59 \pm 0.05$ \\
UW1966 & $2.04 \pm 0.28$ & None & $4.88 \pm 0.37$ & $2.17 \pm 0.19$ & & $1.15 \pm 0.08$ \\
\hline
\end{tabular}

*Due to a $2^{\text {nd }}$ glow growth curve with a large negative intercept (not expected from current understanding), the additive dose intercept was used for equivalent dose.

Table 4 gives the ages calculated separately for TL, IRSL, and OSL for each sample. For samples with evidence of fading of the TL signal, the correction procedure of Huntley and Lamothe (2002) was applied. In some cases, this correction did not produce a significantly older age, although part of the reason for this may be low precision in the fading data. No fading tests were done for either IRSL or OSL (because of exorbitant amount of machine time required), so no correction can be applied to them. The IRSL signal mainly comes from feldspars, which often fade, so the IRSL ages must be considered a minimum. The weak IRSL, and therefore feldspar, signal suggests that the OSL signal probably comes mainly from quartz and does not fade, as mentioned earlier.

Table 4. Age calculations for TL, IRSL, and OSL for Pine Snake site samples.

\begin{tabular}{l|lll}
\hline Sample & TL age $(\mathrm{ka})$ & IRSL age $(\mathrm{ka})$ & OSL age $(\mathrm{ka})$ \\
\hline UW1964 & $2.52 \pm 0.98$ & & $0.58 \pm 0.05$ \\
UW1965 & $0.58 \pm 0.14$ & $0.41 \pm 0.20$ & $0.51 \pm 0.04$ \\
UW1966 & $0.81 \pm 0.16^{*}$ & & $1.57 \pm 0.15$ \\
\hline
\end{tabular}

* Corrected for fading using Huntley and Lamothe (2002) method.

Other TL ages reflect either no measured fading or a correction that was not significantly different from the uncorrected age.

** Sample fades, but correction produced infinite value 
Table 4 shows that the OSL age is typically younger than, or equivalent in value to, the TL and IRSL ages. It is clearly younger for two samples from the Pine Snake site, and for UW1965, it is probably younger because the TL age is underestimated due to insignificant fading correction because of poor precision. On one sample (UW1966), the OSL age is older, even when fading of the TL signal is considered.

The younger OSL ages are unusual. The OSL is usually older, if anything, because of fading for TL and IRSL. A possible reason is the low original firing temperature of the pottery. It is well known in the citse of light exposure that the traps associated with TL and IRSL do not bleach as rapidly as they do for OSL. It is possible the original firing of the pottery was not sufficient to deplete the TL and IRSL signals to the same extent as the OSL signal. In other words, the TL and IRSL still contain a residual signal from the raw material. That would make the OSL ages the most likely ages for the manufacture of the pottery, but OSL is also known to contain slower bleaching components, so it is possible that a residual is present even with the OSL.

Assuming the OSL is the best estimate in most cases, Table 5 gives the final ages for the Pme Snake samples. Some additional comments: the OSL age for UW1966 seemed unreasonably old, so the TL Wia taken as the best estimate.

Table 5. OSI and TL final age estimates for Pine Snake site samples.

\begin{tabular}{l|cccc}
\hline Sample & Age (ka) & \% error & Calendar age (vears .AD) & Basis for uge* \\
\hline UW1964 & $0.58 \pm 0.05$ & 8.4 & $1430 \pm 50$ & OSL \\
UW1965 & $0.51 \pm 0.04$ & 7.7 & $1490 \pm 40$ & OSL \\
UW1966 & $0.53 \pm 0.08$ & 15.1 & $1470 \pm 80$ & TL \\
\hline * OSL/TL refers to a weighted average of the two ages \\
** negative value reflects a BC age
\end{tabular}

The ages for samples from Pine Snake are all considerably older than expectations, as they range from A.D. 1380-1550 at one standard deviation and A.D. 1330-1630 at two standard deviations, as compared to the post-A.D. 1650 temporal estimate derived from the analysis of the recovered ceramics from the site (see below). Insufficient heating may be causing the age overestimation. Many of the ccranics were reported as "soft" hy the students preparing them for measurement. I do not consider this a fully satisfactory explanation (the last batch of Caddo ceramics we processed [from the Lang Pasture site in Anderson County, Texas, see Feathers 2011] also had poor plateaus indicative of low heating, but the OSL and TL agreed for most of them and the ages were not known to be overestimates), but I can think of no other reason why the OSL ages should be younger. A possible test could be coarse-grain analysis on UW1964, the sample of burned earth from the hearth feature. Coarse grains of quartz were isolated from this sample. It should be possible to measure only the fast component of these quartz grains - the ones most likely reset to zero - to see if an age more in line with expectations can be obtained.

\section{RECOVERED ARTIFACTS}

More than 580 artifacts are in the assemblage of recovered material culture remains from the Pine Snake site. The majority of the artifacts are ceramic sherds $(n=462)$ from plain, utility ware, and fine ware vesscls. There are also engraved ceramic elbow pipe sherds $(n=3)$ and burned clay pieces $(n=64)$ in the collection. Lithic artifacts include seven arrow points or arrow point preforms, a llake tool, a mano fragment, 47 pieces of lithic debris, and one core.

Plotting the distribution of artifacts recovered in situ at the site, with one exception (a single sherd at 22 $\mathrm{cm}$ bs), all of these artifacts ( $\mathrm{n}=45$ ) are found between $24-36 \mathrm{~cm}$ bs. The highest densities of artifacts by depth occur between $27-28 \mathrm{~cm}$ bs (18\%), $30 \mathrm{~cm}$ bs (11\%), $32 \mathrm{~cm}$ bs (11\%), and $35-36 \mathrm{~cm}$ bs (27\%). These artifacts arc at depths that indicate they are from the large hearth or in deposits immediately above and/or coeval with 
the hearth (i.e., they are in deposits raked out of the hearth and deposited adjacent to it). Mussel shell pieces are particularly abundant below $31 \mathrm{~cm}$ bs, in the lower part of the basin hearth.

\section{Ceramic Sherds}

A total of 462 ceramic sherds were noted in the various positive shovel tests and excavated units at the site. This comprised 157 plain rim, body, and base sherds and 305 decorated rim and body sherds, among them several Patton Engraved sherds, including a rim from ST $778(10-20 \mathrm{~cm}$ bs). The plain to decorated sherd ratio is 0.52 , consistent with an Historic Caddo occupation in the upper Neches River basin (Perttula and Nelson 2007:Table 4; Walters and Perttula 2012:Table 31) as well as the latest Frankston phase (ca. A.D. 1600-1650) Caddo ceramic assemblages (see below).

Most of the decorated sherds have brushing on them, either as the sole form of decoration ( $n=253$ ), or in combination with punctated $(n=3)$ and incised $(n=4)$ lines; these are all from utility ware jars (i.e., cooking jars). The brushed sherds that were noted include vertical brushing on the rim $(n=5)$; horizontal brushing on rims $(n=4)$; horizontal brushing on the rim and vertical brushing on the body $(n=1)$; parallel brushed $(n=208)$; overlapping brushed $(n=12)$; vertical brushed on the body $(n=18)$; and opposed brushing $(n=5)$. Overall, $85 \%$ of the decorated sherds from the site have brushed marks on either the rim and/or the body of utility ware jars; this is one of the highest proportion of brushed sherds documented to date in any Caddo site in the upper Neches River basin other than a series of historic Caddo sites on nearby Stone Chimney Creek (see also Perttula and Nelson 2007:Table 4; Walters and Perttula 2012:Table 31).

Other decorated utility ware sherds include brushed-punctated sherds. These include vessels with a tool punctated rim and horizontal brushing on the body $(n=2)$, as well as one body sherd with parallel brushing, and a row of tool punctates pushed through the brushing, and parallel brushed-overlapping and/or diagonal incised lines over the brushing $(n=2)$. There are also two Spradley Brushed-Incised body sherds, a new utility ware ceramic type documented in Historic Caddo contexts in the Neches-Angelina river basin (Marceaux 2011). These sherds have parallel brushing overlain with closely-spaced perpendicular incised lines.

Other utility ware sherds are present at the Pine Snake site, although in low proportions (as is also the case at the Kah-hah-ko-wha site [41CE354], see Perttula and Nelson [2007:Table 5]). There are five sherds (including two rims) from LaRue Neck Banded jars, and two body sherds with closely spaced pinched rows from Killough Pinched jars.

A Maydelle Incised rim with triangular incised zones filled with punctations was found in ST 554 (20-40 $\mathrm{cm}$ bs), and there are two body sherds with tool punctated rows, and five body sherds with parallel or opposed incised lines. Another body sherd has a vertical appliqued fillet and opposed incised lines, and one body sherd has a straight appliqued fillet. A third appliqued sherd in the decorated sherd assemblage has a straight appliqued fillet with a row of tool punctations placed adjacent to the fillet.

There are a number of $\operatorname{rim}(n=3)$ and body sherds $(n=6)$ with horizontal or parallel grooved ridges in the Pine Snake utility wares. Very similar decorated sherds have been recovered at several other historic Caddo sites in the Angelina and Neches River basins in East Texas-including at the Deshazo site (41NA27) (Fields 1995:199-200 and Figure 75d-e) - and this kind of grooved utility ware has recently been dubbed Lindsey Grooved because of its abundance at the Lindsey site (4ICE293) (Marceaux 2011). Although categorized as "ridged" pottery at the Deshazo site, Fields (1995:199-200) describes the decorative technique as "the manipulation of the vessel surface to form shallow horizontal grooves alternating with mounded ridges. The grooves are trough shaped and the ridges are not appliqued." To avoid confusion with the Belcher Ridged type, and its very different form of ridged decoration, we have chosen to emphasize the horizontal grooves as the defining criteria for this new Caddo utility ware type.

In the fine wares at the Pine Snake site, there are five Patton Engraved rim and body sherds. These 
are all apparently from Patton Engraved, var. Allen vessels (see Perttula 2008:Figure 2) with horizontal rows of engraved lines with triangular tick marks.

There are 13 other fine ware sherds recovered in the investigations. These include a bottle sherd with opposed engraved lines; two sherds with multiple curvilinear engraved lines; two possible carinated bowl sherds with part of a scroll element; two possible Poynor Engraved, var. Hood sherds with hatched panel dividers (see Perttula 2008:Figure 1); a body sherd with opposed engraved lines; and a rim to an inverted rim carinated bowl (likely a Patton or Poynor Engraved vessel, see Suhm and Jelks 1962) with one horizontal engraved line showing on it. Two other rims have a single horizontal engraved line under the lip, and one of these is also lip notched; this is a rare form of lip treatment in the upper Neches River basin Caddo ceramic tradition (Perttula 2011). Another sherd from a carinated bowl has a single horizontal engraved line above the carination, and horizontal brushing on the vessel body.

The last fine ware engraved sherd from the Pine Snake site is a Hume Engraved, var. Allen sherd (see Perttula 2008:Figure 2). This sherd is fron a bowl or carinated bowl with at least one horizontal engraved line that has a series of hatched pendant triangles.

As previously mentioned, the Pine Snake site has one of the highest proportions of brushed sherds in any documented Caddo ceramic assemblage in this part of the upper Neches River basin (Table 6), and thus it falls into the Group 1 assemblages, the youngest Caddo sites in our present sample along with the ceramic sherd assemblage from the nearby Kah-Hah-Ko-Wha site (41CE354) and several sites on Stone Chimney Creek (41CE421 and 41CE429). The Group 1 sites are all identified as having Historic Caddo Allen phase components.

Table 6. Comparative sherd assemblage data from Lake Palestine Caddo sites, nearby Caddo sites, and the Pine Snake site.

\begin{tabular}{|c|c|c|c|c|c|c|}
\hline Site & \multicolumn{2}{|l|}{ Sherds } & \multicolumn{2}{|c|}{$\begin{array}{l}\text { \%bone- \% Wet-paste } \\
\text { temper decorations }\end{array}$} & $\mathrm{P} / \mathrm{DR}$ & $\begin{array}{l}\text { Brushed/Wet } \\
\text { paste ratio }\end{array}$ \\
\hline \multicolumn{7}{|c|}{ YOUNGEST SITES: GROUP I, Allen phase } \\
\hline $41 \mathrm{CE} 421$ & 2353 & 89.5 & 5.4 & 7.8 & 0.28 & 8.5 \\
\hline $41 \mathrm{CE} 429$ & 465 & 87.7 & 0.8 & 9.7 & 0.22 & 9.07 \\
\hline Pine Snake* & 305 & 85.2 & 5.7 & 8.8 & 0.51 & 9.63 \\
\hline $41 \mathrm{CE} 354 *$ & 474 & 82.7 & 3.1 & 8.9 & 0.20 & 8.14 \\
\hline \multicolumn{7}{|c|}{ GROUP II, latest Frankston phase, ca. A.D. $1560-1650$} \\
\hline $41 \mathrm{CE} 324$ & 188 & 81.9 & 3.2 & 7.3 & 0.48 & 11.0 \\
\hline Debro & 311 & 80.0 & ? & 10.3 & 0.14 & 7.75 \\
\hline $\begin{array}{l}\text { William } \\
\text { Sherman }\end{array}$ & 525 & 75.8 & $?$ & 16.2 & 0.44 & 4.68 \\
\hline \multicolumn{7}{|c|}{ GROUP III, Frankston phase, ca. A.D. $1480-1560$} \\
\hline Forest Drive & 1693 & 68.6 & $?$ & 21.9 & 0.56 & 3.12 \\
\hline Halbert & 1757 & 65.8 & 2.6 & 26.3 & 0.70 & 2.51 \\
\hline Woldert & 1730 & 62.7 & 0.0 & 28.8 & 0.72 & 2.19 \\
\hline Ferguson & 4116 & 60.8 & $<1.0$ & 27.9 & 0.61 & 2.17 \\
\hline \multicolumn{7}{|c|}{ GROUP IV, earliest Frankston phase, ca. A.D. I400-1480 } \\
\hline Tomato Patch & 912 & 49.2 & $?$ & 41.7 & 1.50 & 1.21 \\
\hline Lang Pasture & 2435 & 35.9 & 6.7 & 38.0 & 1.40 & 0.91 \\
\hline Mitchell, D & 54 & 32.1 & 0.0 & 33.3 & 1.37 & 1.50 \\
\hline
\end{tabular}


Table 6. Comparative sherd assemblage data from Lake Palestine Caddo sites, nearby Caddo sites, and the Pine Snake site, cont.

\begin{tabular}{|c|c|c|c|c|c|}
\hline Site & $\begin{array}{l}\text { No. of Dec. } \\
\text { Sherds }\end{array}$ & \%Brushed & $\begin{array}{l}\text { \%bone- } \% \text { Wet-paste } \\
\text { temper decorations }\end{array}$ & $\mathrm{P} / \mathrm{DR}$ & $\begin{array}{l}\text { Brushed/Wet } \\
\text { paste ratio }\end{array}$ \\
\hline
\end{tabular}

\begin{tabular}{lllllll}
\hline GROUP V, Middle Caddo period, ca. A.D. $1200-1400$ & & & \\
41SM404 & 446 & 16.0 & 8.5 & 60.7 & 1.73 & 0.26 \\
White Mule & 1404 & 18.5 & 1.5 & 63.7 & 2.61 & 0.29 \\
41 HE139 & 40 & 17.5 & 8.1 & 65.0 & 2.51 & 0.33
\end{tabular}

OLDEST SITE: GROUP VI, Early Caddo period, ca. A.D. 1000- 1200

$\begin{array}{lllllll}\text { Mitchell, A-C } & 56 & 1.3 & 12.0 & 65.7 & 1.71 & 0.03\end{array}$

*sites with Patton Engraved sherds

Sources: Anderson et al. 1974; Perttula 2009, 20I1; Perttula and Middlebrook 2009; Walters and Perttula 2012

The Pine Snake ceramics are tempered with grog or crushed sherds/fired clay (Table 7). Grog is a temper in each of the sherds analyzed in detail, regardless of whether the sherd is from a plain ware, utility ware, or fine ware vessel.

Table 7. Temper and paste attributes of the Pine Snake ceramics.

\begin{tabular}{|c|c|c|c|c|}
\hline Temper-paste & Utility ware & Fine ware & Plain ware & $\mathbf{N}$ \\
\hline grog & 26 & 3 & 9 & 38 \\
\hline grog-sandy paste & 12 & - & 5 & 17 \\
\hline grog-hematite & 12 & 1 & 4 & 17 \\
\hline sandy paste & 6 & 2 & 1 & 9 \\
\hline $\begin{array}{l}\text { grog-bone } \\
\text { grog-bone- }\end{array}$ & 1 & - & 2 & 3 \\
\hline $\begin{array}{l}\text { sandy paste } \\
\text { grog-bone- } \\
\text { organics-sandy }\end{array}$ & - & - & 1 & 1 \\
\hline paste & - & - & 1 & 1 \\
\hline $\begin{array}{l}\text { grog-organics- } \\
\text { sandy paste }\end{array}$ & - & 1 & - & 1 \\
\hline total with grog & $100.0 \%$ & $100.0 \%$ & $100.0 \%$ & 87 \\
\hline total with bone & $1.8 \%$ & $0.0 \%$ & $17.4 \%$ & 5 \\
\hline total with hematite & $31.6 \%$ & $42.9 \%$ & $21.7 \%$ & 26 \\
\hline $\begin{array}{l}\text { total with organics } \\
\text { total with sandy }\end{array}$ & $0.0 \%$ & $14.3 \%$ & $4.3 \%$ & 2 \\
\hline paste & $31.6 \%$ & $42.9 \%$ & $34.8 \%$ & 29 \\
\hline Totals & 57 & 7 & 23 & 87 \\
\hline
\end{tabular}


Less than $6 \%$ of the sherds from the site (with the highest proportions found in the plain wares) are from vessels with bone temper inclusions (see Table 7); the limited use of bone as a temper is characteristic of the upper Neches River basin Caddo ceramic tradition (Perttula 2011; see Table 6). Crushed pieces of hematite or ferruginous sandstone are also regularly used (29.9\%) as a temper in the Pine Snake ceramics, especially so in the fine wares. Two sherds $(2.3 \%)$ have charred organic remains in the paste, suggesting they are from vessels where the clay paste was not well-cleaned belore firing and/or that they are from low-fired vessels wherc the organic materials in the paste were not completely combusted during firing.

More than $33 \%$ of the sherds from the Pine Snake site are from vessels that have been made with a naturally sandy clay. Each of the different ceramics warcs at the site relied on roughly comparable proportions of sandy clays (i.e., sandy paste, 31.6-42.9\%), with their greatest use seen in the engraved line wares (see Table 7).

The majority of the sherds from the Pine Snake site are from vessels fired in a low oxygen or reducing environment (Table 8). The sherds fired in this manner comprise between $57.9 \%$ (utility wares) and $71.5 \%$ (fine wares). Plain wares were generally fired in the same manner as the fine wares, as $69.5 \%$ of the plain sherds are from vessels fired in a reducing environment.

Table 8. Firing conditions in the Pine Snake site ceramic sample.

\begin{tabular}{lllll}
\hline Firing Condition & Utility ware & Fine ware & Plain ware & $\mathrm{N}$ \\
\hline $\begin{array}{l}\text { Oxidizing } \\
\begin{array}{l}\text { Incompletely } \\
\text { oxidized }\end{array}\end{array}$ & $14.0 \%$ & $14.3 \%$ & $0.0 \%$ & 9 \\
$\begin{array}{l}\text { Reducing } \\
\begin{array}{l}\text { Reducing, but } \\
\text { cooled in } \\
\text { open air }\end{array}\end{array}$ & $52.1 \%$ & $14.3 \%$ & $30.4 \%$ & 19 \\
$\begin{array}{l}\text { Sooted, smudged, } \\
\text { reheated }\end{array}$ & $7.0 \%$ & $28.6 \%$ & $13.0 \%$ & 8 \\
\hline$\quad-72.9 \%$ & $56.5 \%$ & 46 \\
Totals & 57 & $0.0 \%$ & $0.0 \%$ & 4 \\
- & 7 & & 87 \\
\hline
\end{tabular}

In particular, the highest proportion of sherds are from vessels fired in a low oxygen environment, but then the vessels were pulled from the fire and allowed to cool in the open air. Depending upon the ware, between $42.9-56.5 \%$ of the sherds from the site are from vessels fired in this manner; plain wares were most conmonly fired this way. Ahout $23 \%$ of the sherds are from incompletely oxidized vessels (see Table 8 ); that is, the vessels were not fired a sufficient duration to completely oxidize the paste. Almost $5 \%$ of the sherds analyzed in detail for firing conditions are from utility ware vessels that have been either sooted, smudged, or reheated, leaving a thin dark reduced band along one or both vessel sherd surfaces.

\section{Instrumental Neutron Activation Analysis of Selected Sherds}

Six ceramic sherds and one ceramic elbow pipe sherd from the Pine Snake site (Table 9) were submitted to the Archaeornetry Laboratory at the Research Reactor Center at the University of Missouri-Columbia for instrumental neutron activation analysis (INAA) (Ferguson 2009a). The purpose of these analyses is to determine, in so far as is possible, the production lociale of the analyzed sherds, and identify any ceramic sherds that are from vessels made from non-local clay sources (i.e., are from a trade vessel). In the analysis, Ferguson (2009a) 
projected the new sherd samples from the Pine Snake site against the sub-regional groups developed in the latest reworking of the Caddo ceramic database. The Pine Snake site is in ceramic compositional sub-regional group 8, primarily comprised of sherds from sites in the upper Neches River basin; each of the samples from the Pine Snake site have been compared to the current compositional group structure.

Table 9. Samples submitted for instrumental neutron activation analysis from the Pine Snake site.

\begin{tabular}{lllll}
\hline $\begin{array}{l}\text { Sample } \\
\text { No. }\end{array}$ & $\begin{array}{c}\text { Site } \\
\text { Name }\end{array}$ & $\begin{array}{l}\text { Region } \\
\text { No. } \\
\text { (River Basin) }\end{array}$ & Description & $\begin{array}{c}\text { Age } \\
\text { (A.D.) }\end{array}$ \\
\hline TKP896 & Pine Snake & 8 (Neches) & elbow pipe rim & $1650-1720$ \\
TKP897 & Pine Snake & 8 (Neches) & parallel brushed sherd & $1650-1720$ \\
TKP898 & Pine Snake & 8 (Neches) & $\begin{array}{l}\text { Maydelle Incised rim } \\
\text { parallel incised body sherd }\end{array}$ & $1650-1720$ \\
TKP899 & Pine Snake & 8 (Neches) & $1650-1720$ \\
TKP900 & Pine Snake & 8 (Neches) & $\begin{array}{l}\text { parallel brushed sherd } \\
\text { brushed-punctated sherd }\end{array}$ & $1650-1720$ \\
TKP901 & Pine Snake & 8 (Neches) & $1650-1720$ \\
TKP902 & Pine Snake & 8 (Neches) & Lindsey Grooved sherd & $1650-1720$ \\
\hline
\end{tabular}

Sub-region 8 INAA samples consist of a core group ( $n=111)$, Group $1(n=7)$, Group $2(n=12)$, and 17 unassigned samples. The Pine Snake sherd samples are good matches with the sub-region 8 core group (see Ferguson 2009a:Figure 3), strongly suggesting that the sherds are from vessels and pipes made from local clay sources.

\section{Ceramic Pipe}

A large section of a ceramic elbow pipe, made from local clays (see above) was noted at $28 \mathrm{~cm}$ bs in ST 778 at the southern end of the Pine Snake site (see Figures 1 and 2). This pipe is very similar to other Late Caddo and Historic Caddo elbow pipes documented in the upper Neches River basin (probably Var. B), as it has four horizontal engraved lines on the stem, as do several other varieties of elbow pipes from this region (see Perttula 2011). The bowl and lower stem sections of the pipe fragment have a series of concentric engraved circles.

Other pipe sherds were recovered from Units $782(26 \mathrm{~cm} \mathrm{bs})$ and $784(10-20 \mathrm{~cm} \mathrm{bs})$. In the case of Unit 782 , a large section (three conjoined sherds) of an elbow pipe stem was found. This bone-tempered stem had four horizontal engraved lines below the stem lip, as well as at least seven vertical engraved lines that extend down the stem towards the pipe bowl. This is an example of a Var. C elbow pipe (Perttula 2011:Figure 6-23). The Unit 784 pipe sherd has at least two horizontal engraved lines encircling the pipe stem below the lip.

\section{Burned Clay}

About 64 pieces of burned clay were noted in ST $778(20-40 \mathrm{~cm}$ bs) and three excavation units (Units 781 and 786, between $20-35 \mathrm{~cm} \mathrm{bs}$ ). These may be part of the clay lining of the basin-shaped hearth exposed in this small excavation.

\section{Chipped Stone Tools}

An interesting assortment of chipped stone tool fragments and lithic debris were noted in the shovel tests excavated at the Pine Snake site. Chipped stone tools noted in the investigations include several arrow points or arrow point fragments - Perdiz arrow points $(n=3$, ST $554,0-20 \mathrm{~cm}$ bs, gray chert, ST 778, 0-10 $\mathrm{cm}$ bs, dark gray chert, ST 778, 10-20 cm bs, gray chert); a contracting stem arrow point preform of white 
novaculite (ST 558, 20-40 cm bs); a possible Bassett point fragment of gray chert (ST 778, 20-30 cm b); arrow point tip and blade fragments ( $\mathrm{n}=2$, ST $556,40-60 \mathrm{~cm}$, quartzite, ST 778, 30-40 cm bs, gray chert) - and a distally-retouched flake tool of gray chert (ST $565,0-20 \mathrm{~cm}$ bs).

\section{Ground Stone Tools}

A single ferruginous sandstone mano fragment (with grinding on both surfaces) was found in Unit 785 between $20-30 \mathrm{~cm}$ bs. This two-sided mano is at least $40 \mathrm{~mm}$ in length, $52 \mathrm{~mm}$ in width, and $18 \mathrm{~mm}$ in thickness.

\section{Lithic Debris}

The lithic debris from the site includes flakes from several different raw materials: gray chert $(n=31)$, brownish-gray chert $(n=1)$, dark gray chert $(n=3)$, honey-colored chert $(n=1)$, a translucent brown chert $(n=1)$, dark brown chert $(n=1)$, black chert $(n=2)$, a glassy black siliceous material (obsidian, $n=2$, ST 778, 10-20 $\mathrm{cm}$ bs and Unit 785, 10-20 $\mathrm{cm} \mathrm{bs})$, and quart7ite $(\mathrm{n}=5)$. These flakes are the product of the resharpening or final pressure-flaking of completed or near-completed tools that must have been brought to the site, except for the quartzite pieces; the latter raw material occurs as pebbles in local stream gravels, and they were reduced through knapping to obtain flakes for tool use or arrow point manufacture. There is a sinall tested quartzite pebble from Unit $784(10-20 \mathrm{~cm}$ bs $)$; it is $46 \mathrm{~mm}$ in length, $29 \mathrm{~mm}$ in width, and $28 \mathrm{~mm}$ in thickness.

Chert comprises about $85 \%$ of the lithic debris at the site, all from non-local raw material sources. These include Central Texas sources 150 miles or more to the west (i.e., the gray, brownish-gray, dark gray, honey-colored, translucent brown, and dark brown cherts; several flakes have a limestone-covered cortex) or Ouachita Mountains sources (i.e., the black chert) more than 100 miles to the north.

The obsidian (Texas Obsidian Project No. 234a-c) is from a long-distance non-local source, namely from the Obsidian Ridge (Cerro de Toledo rhyolite) source in the Jemez Mountains of northern New Mexico (Thomas R. Hester, April 27, 2009 personal communication). According to Ferguson (2009b), the obsidiaı pieces were analyzed by the University of Missouri Research Reactor Center with a hand-held portable Bruker XRF:

the instrument has a rhodium-based X-ray tube which we operate at $40 \mathrm{kV}$ and a thermoelectrically cooled silicon detector. We calibrated the instrument using a suite of 45 well-known obsidian sources with data from previous XRF and NAA measurements. Your samples were counted for three minutes to measure the minor and trace clements present. The elements measured include $\mathrm{Mn}, \mathrm{Fe}, \mathrm{Zn}, \mathrm{Ga}, \mathrm{Pb}, \mathrm{Th}, \mathrm{Rb}, \mathrm{Sr}, \mathrm{Y}, \mathrm{Zr}$, and $\mathrm{Nb}$... The resulting data were compared to our database of obsidian sources using both hierarchical cluster analysis and bivariate plots. Due to the small size of the artifacts, the concentrations of lower atomic weight elements are inflated with the smallest samples, thus the source assignment was based primarily on elements $\mathrm{Rb}, \mathrm{Sr}, \mathrm{Y}, \mathrm{Zr}$, and $\mathrm{Nb}$.

The mean values in parts per million $(\mathrm{ppm})$ for these elements are: $\mathrm{Rb}(196.3 \pm 5.6 \mathrm{ppm}), \mathrm{Sr}(5.67+$ $0.44 \mathrm{ppm}), \mathrm{Y}(47 \pm 2.67 \mathrm{ppm}), \mathrm{Zr}(153.7 \pm 10.23 \mathrm{ppm})$, and $\mathrm{Nb}(71.3+2.23 \mathrm{ppm})$.

\section{ANIMAL AND PLANT REMAINS}

Animal bone pieces $(\mathrm{n}=8)$ were noted in several shovel tests, including ST $576(0-20 \mathrm{~cm}$ bs $)$ in the northern area and ST $550(0-20 \mathrm{~cm}$ bs $), 555(0-15 \mathrm{~cm}$ bs), and $558(20-40 \mathrm{~cm}$ bs; arnong them deer teeth) in the southern ceramic concentration (see Figure 1). ST $558(20-40 \mathrm{~cm}$ bs) also had a mussel shell fragment. Burned animal bone, wood charcoal, nutshell, and mussel shell fragments were also noted between 10-40 $\mathrm{cm}$ bs in ST 778. They are also relatively abundant in the $1 \times 1 \mathrm{~m}$ excavation units placed in and around the Feature 1 hearth. These remains have not been studied to date. 


\section{SUMMARY AND CONCLUSIONS}

The Pine Snake site is one of several well-preserved Historic Caddo Allen phase settlements that have been recently identified in a small portion of the Flat Creek valley in the upper Neches River basin (Perttula 2009; Perttula and Nelson 2007, 2009a, 2009b), as well as in nearby Stone Chimney Creek (Walters and Perttula 2012). It is apparent from the number of sites that have been documented in this area that there was a considerable density of Caddo residential settlements on these Neches River tributaries in the late $17^{\text {th }}$ early $18^{\text {th }}$ century, which is not generally the case in other parts of the upper Neches that have been closely examined by archaeologists. Test excavations at the Kah-Hah-Ko-Wha (4ICE354) and Pine Snake sites have recovered important information on the domestic character of these Historic Caddo settlements, particularly their material culture: including the kinds of ceramic vessels and pipes that were made, decorated, and used during each occupation, the access of these Caddo to exotic lithic raw materials for tool manufacture, and the range of animals, wild plant foods, and domesticated plant foods (see Perttula and Nelson 2007:117-124) that comprised their diet.

Unfortunately, these sites are in an area slated for development by a private landowner, and they are not currently protected from future devclopment. Hopefully, a plan can be developed that is agreeable to the private landowner that will insure the long-term protection and preservation of these heretofore unique and significant Caddo archaeological resources.

\section{REFERENCES CITED}

Anderson, K. M., K. Gilmore, O. R. McCormick III, and E. P. Morenon

1974 Archaeological Investigations at Lake Palestine, Texas. Contributions in Anthropology No. 11. Department of Anthropology, Southern Methodist University, Dallas.

Cole, N. M.

1975 Early Historic Caddoan Mortuary Practices in the Upper Neches Drainage, East Texas. Master's thesis, Department of Anthropology, The University of Texas at Austin.

Feathers, James

2010 Luminescence Analysis of Ceramics from Four Caddo Sites in East Texas. Luminescence Dating Laboratory, University of Washington, Seattle.

2011 Luminescence Dating of Ceramics from the Lang Pasture Site. In Archeological Investigations at the Lang Pasture Site (41AN38) in the Upper Neches River Basin of East Texas, assembled and edited by T. K. Perttula, D. B. Kelley, and R. A. Ricklis, pp. 579-590. Report No. 129. Archeological Studies Program, Environmental Affairs Division, Texas Department of Transportation, Austin.

Ferguson, J. R.

2009a Letter report (April 29, 2009) on the instrumental neutron activation analysis of 38 Caddo ceramic samples. Archaeometry Laboratory, Research Reactor Center, University of Missouri-Columbia.

2009b Letter report (April 29,2009) on the analysis of obsidian samples from the Pine Snake site. Archaeometry Laboratory, Research Reactor Center, University of Missouri-Columbia.

Fields, R. C.

1995 Analysis of Native-Made Ceramics. In The Deshazo Site, Nacogdoches County, Texas, Volume 2: Artifacts of Native Manufacture, edited by D. A. Story, pp. 173-232. Studies in Archeology 21. Texas Archeological Research Laboratory, The University of Texas at Austin. 
Huntley, D. J. and M. Lamothe

2001 Ubiquity of anomalous fading in K-leldspars, and measurement and correction for it in optical dating. Canadian Journal of Earth Sciences 38:1093-1106.

Marceaux, P.S.

2007 Recent Research on the Archaeological and Historical Evidence of the Hasinai. Journal of Northeast Texas Archaeology 26:82-98.

2011 The Archaeology and Ethnohistory of the Hasinai Caddo: Material Culture and the Course of European Contact. Ph.D. dissertation, Department of Anthropology, The University of Texas at Austin.

Mowery, I. C. and H. Oakes

1959 Soil Survey of Cherokee County, Texas. United States Department of Agriculture, Washington, D.C.

Perttula, T. K.

2007a One Attempt at Defining Allen Phase Ceramic Subclusters. Journal of Northeast Texas Archaeology $26: 77-81$.

2007b Upper Neches River Basin Caddo Ceramics: An Attempt at an Updated Seriation and a Context for Understanding Frankston to Allen Phase Ceramic Stylistic and Technological Changes. Journal of Northeast Texas Archaeology 26:154-158.

2008 Trends and Varieties in Late Caddo and Historic Caddo Fine Ware Pottery Types in the Upper Neches River Basin. Journal of Northeast Texas Archaeology 28:51-55.

2009 Ceramic Vessel Sherds from the Kah-Hah-Ko-Wha Site (41CE354), an Allen Phase Component in Northwestern Cherokee County, Texas. Journal of Northeust Texus Archaeology 29:59-79.

2010 Archaeological Findings from an Historic Caddo Site (41 AN184) in Anderson County, Texas. Journal of Northeast Texas Archaeology 33:53-61.

2011 The Ceramic Artifacts from the Lang Pasture Site (41AN38) and the Place of the Site within an Upper Neches River Basin Caddo Ceramic Tradition. In Archeological Investigations at the Lan: Pasture Site (4IAN38) in the Upper Neches River Basin of East Texas, assembled and edited by $\Gamma$. K. Perttula, D. B. Kelley, and R. A. Ricklis, pp. 145-320. Report No. 129. Archeological Studies Program, Environmental Affairs Division, Texas Department of Transportation, Austin.

Perttula, T. K. and T. Middlcbrook

2009 Prehistoric Caddo Ceramics from the Henry Lake Site (41CE324), Cherokee County, Texas. Journal of Northeast Texas Archaeology 29:9-21.

Perttula, T. K. and B. Nelson

2007 Archeological Survey Investigations and Test Excavations at 41CE354 at the North and South Lake areas of the H.R.C. Cherokee Tree Farm, L.P. Project, Cherokee County, Texas. Report of Investigations No. 80. Archeological \& Environmental Consultants, LLC, Auslin.

2009a Archeological Survey of Additional Lands of the H.R.C. Cherokee Tree Farm, L. P. Project, Cherokee County, Texas. Internal document. Report of Investigations No. 96. Archeological \& Environmental Consultants, LLC, Austin. 
2009b Archeological Survey of 361.3 Acres of the H.R.C. Cherokee Tree Farm, L. P. Project in the Flat Creek Valley, Cherokee County, Texas. Internal document. Report of Investigations No. 98. Archeological \& Environmental Consultants, LLC, Austin.

Shafer, H. J.

2003 Mimbres Archaeology at the NAN Ranch Ruin. University of New Mexico Press, Albuquerque.

Suhm, D. A. and E. B. Jelks (editors)

1962 Handbook of Texas Archeology: Type Descriptions. Initial Series of Descriptions. Special Publication No. 1, Texas Archeological Society, and Bulletin No. 4, Texas Memorial Museum, Austin.

Walters, M. and T. K. Perttula

2012 Certain Caddo Sites on Stone Chimney Creek, Cherokee County, Texas. Journal of Northeast Texas Archaeology 37:37-88.

\section{APPENDIX 1,}

\section{ANALYSIS OF THE RECOVERED ARTIFACTS FROM FINE. SCREEN SAMPLES ASSOCIATED WITH FEATURE 1 AND POST HOLES 1-7}

Ten fine-screen samples were obtained from the Fcature 1 hearth and Post holes 1-7 at the Pine Snake site. The three from Feature 1 (Units $781-783,30-35 \mathrm{~cm}$ bs) are from $40 \times 40 \mathrm{~cm}$ areas: each contained 9.5 liters of featurc sediments. The fine-screen samples from the post holes ranged from 1.3-11.4 liters in size, depending upon the diameter and depth of each of the post holes. A total of 23.5 liters of post hole sediment fill was taken from the post holcs.

The fine-screen samples from the Pine Snake site contain sherds $(n=8)$, burned clay pieces $(>n=520)$, lithic debris $(n=3)$, a ground stone mano $(n=1)$, a single firc-cracked rock, charred plant remains (i.e., wood charcoal and charred nutshells, $>n=907)$, animal bones $(n=124)$, and small pieces (and one valve from Post hole 7) of mussel shell $(n=16)$ (Table 10). With the exception of Post hole 7, the other post holes contain only a low assortment of ceramic sherds, charred plant remains ( $n=55,6 \%$ of the remains), and animal bones (Table 10).

Table 10. Recovery of artifacts from fine-screen samples at the Pine Snake site.

\begin{tabular}{|c|c|c|c|c|c|c|c|c|c|}
\hline Artifact category & $\mathrm{Pl}^{*}$ & $\mathrm{P} 2$ & P3 & P6 & P7 & U781 & U782 & U783 & $\mathrm{N}$ \\
\hline Plain sherd & 1 & & 1 & & & & & 2 & 4 \\
\hline Decorated sherd & & & 1 & & 2 & & & 1 & 4 \\
\hline Burned clay & & & & & $100+$ & $120+$ & $200+$ & $100+$ & $520+$ \\
\hline Lithic debris & & & & & 2 & & 1 & & 3 \\
\hline Ground stone tool & & & & & & & 1 & & 1 \\
\hline Fire-cracked rock & & 1 & & & & & & & 1 \\
\hline Plant remains & 8 & & 29 & 18 & $200+$ & 52 & $400+$ & $200+$ & $907+$ \\
\hline
\end{tabular}


Table 10. Recovery of artifacts from fine-screen samples at the Pine Snake site, cont.

\begin{tabular}{|c|c|c|c|c|c|c|c|c|c|}
\hline Artifact category & $\mathrm{P} 1 *$ & $\mathrm{P} 2$ & P3 & P6 & P7 & U781 & U782 & U783 & $\mathrm{N}$ \\
\hline Animal bone & & & 6 & 1 & 9 & 29 & 47 & 32 & 124 \\
\hline Mussel shell & 2 & & & 1 & 1 & 5 & 2 & 5 & 16 \\
\hline Totals & 11 & 1 & 37 & 20 & $314+$ & $206+$ & $651+$ & $340+$ & $1580+$ \\
\hline
\end{tabular}

*Post holes 4 and 5 did not contain any artifacts

All four decorated sherds are body sherds from utility ware jars that have brushed bodies. Three of the four sherds are from vessels tempered with grog, and the remaining sherd has both grog and crushed paci of ferruginous sandstone/hematite.

Evidence of chipped stone tool manufacture is limited in these fine-screen samples. This consists of three picces of lithic debris, one each of petrified wood (a cortical flake), a cortical flake of dark gray chert, and a non-cortical flake of gray chert. The latter two flakes are likely from completed or near completed tools made of non-local lithic raw materials; such cherts may have been available in gravel sources in the Trinity or Brazos River basins to the west of the Pine Snake site. 